George Gavrilis

\title{
CENTRAL ASIA'S UNCERTAIN RADICALIZATION AND THE OPPORTUNITIES FOR THE RUSSIA-U.S. COOPERATION
}

DOI: 10.20542/2307-1494-2017-1-251-260

Keywords: Central Asia, radicalization, countering violent extremism, Afghanistan, RussiaU.S. cooperation

Abstract: Russia and the United States can use a rare, if limited, spirit of cooperation
across Central Asia in the field of counterterrorism to find an even rarer bilateral
space of cooperation. This article discusses the appetite for cooperation in
Central Asia and the consequences of the knowledge gap across Central Asian
states and international policymakers who sponsor programs to prevent
radicalization that can lead to violent extremism. It concludes by outlining
recommendations that Russian and American officials can follow in concert to
retool existing initiatives and strengthen counterradicalization programs across
Central Asia - removed from the U.S.-Russia tensions over Syria or Europe.

Ключевые Центральная Азия, радикализация, противодействие насильственному слова: экстремизму, Афганистан, российско-американское сотрудничество

Аннотация: Россия и США могут использовать диалог в духе сотрудничества по борьбе с терроризмом в Центральной Азии для того, чтоб расширить поле для двустороннего сотрудничества в целом. В статье обсуждаются возможности и готовность к такому сотрудничеству, а также последствия разрыва между экспертизой и реальностью в области противодействия радикализации и насильственному экстремизму как для стран Центральной Азии, так и для международных доноров соответствующих программ. Статья содержит рекомендации для официальных лиц России и США по пересмотру существующих в этой области инициатив и укреплению программ по противодействию радикализации в Центральной Азии - вне зависимости от противоречий между США и Россией по Сирии или европейской безопасности.

\section{Introduction}

Compared to most other regions of the world, Central Asian states have fared well in suppressing and avoiding acts of terrorism. According to the 2016 Global Terrorism Index, Central Asia is on par with Latin America in seeing relatively low levels of terrorism impact; indeed, even Tajikistan, the Central Asian state which has seen the highest impact of terrorism in the region ranks 56 among countries, far below Russia, the United States, and one notch below Ireland. ${ }^{1}$

Despite this rather enviable position, a host of officials, journalists, and expert observers insist that the region is doing poorly in countering radicalization and on the 
cusp of a terrorist bloodbath. As one article in the "Times of Central Asia" announces: "ISIL activists have already infiltrated Central Asian countries..."; "In Tajikistan and Uzbekistan, there were cases of open demonstration of ISIL's flags in the main streets of Dushanbe and Tashkent." ${ }^{2}$ Speaking with regional experts at an OSCE conference in 2016, former President of Kyrgyzstan Rosa Otunbayeva cited the country's radicalization problem stating, "Islamists are struggling with us. We have a literal war. They are fighting for each meter of our lives." 3 Given terror incidents in Europe and neighboring Afghanistan, Central Asian officials expect that they will be the next targets.

These perceptions have helpful and less helpful aspects. On a positive note, Central Asian officials are worried enough to take action. They insist that sustainable counterterrorism policies must include partnerships with local communities and civil associations, but such insistence is rarely followed up with holistic programs to prevent the kinds of radicalization that can lead to violence and terrorism. ${ }^{4}$ This failure has less to do with weak state capacity or political unwillingness to work with communities; rather, it is rooted in ignorance of the drivers and true extent of radicalization. Central Asian officials do not have a clear way to gauge the extent of radicalization within their own territories, nor do they understand its root causes.

Here, Russia and the United States can use a rare, if limited, spirit of cooperation across Central Asia in the field of counterterrorism to find an even rarer bilateral space of cooperation. This article discusses the appetite for cooperation in Central Asia and the consequences of the knowledge gap across Central Asian states and international policymakers who sponsor programs to prevent radicalization that can lead to violent extremism. It concludes by outlining recommendations that Russian and American officials can follow in concert to retool existing initiatives and strengthen counterradicalization programs across Central Asia - removed from the U.S.-Russia tensions over Syria or Europe - where each can bring to the table what it does best in the prevention of violent extremism.

\section{Appetite for cooperation}

In recent years, Central Asian states have demonstrated greater interest and willingness to cooperate with one another on counterterrorism - in part, because they see it as preferable to other types of cooperation. ${ }^{5}$ In November 2011, representatives of Kazakhstan, Kyrgyzstan, Tajikistan, and Turkmenistan came together in Ashgabat to sign a Joint Plan of Action for the Implementation of the United Nations Global Counterterrorism Strategy. ${ }^{6}$ This plan of action followed months of high-level meetings, and the signatories agreed to undertake 40 measures to prevent terrorism and address issues conducive to the spread of terrorism.

This willingness to cooperate has deepened in 2016-2017 for at least two reasons. First, officials are concerned that they are unprepared to deal with the ripple effects of a military defeat of ISIS in Syria and Iraq. This includes the return of foreign terrorist fighters from Syria and Iraq to their countries of origin in Central Asia. As one group of 
experts explains, "Some will return truly disaffected and as actual defectors from the group, while others will only be disillusioned but still longing to build an 'Islamic Caliphate'. Others will be sent back to recruit and attack at home". ${ }^{7}$ Second, there is growing fear that the region's security apparatuses are not equipped to detect and deter small cells of radicalized individuals. ${ }^{8}$

Even Uzbekistan, the Central Asian state that, along with Turkmenistan, has been the least likely to participate in multilateral initiatives, has been shadowing many of the counterterrorism and preventative measures that other states have followed in the region. There is reason to be optimistic that this trend that began well before President Islam Karimov's death in 2016 will continue under President Shavkat Mirziyoyev.

Central Asian officials have come to recognize that they need to go beyond hard security measures and admit that they are searching for better ways to engage with communities and public associations to prevent radicalization in the region and deradicalize those who have internalized violent extremist ideology. For example, an official from Kazakhstan explained that such approaches must be more proactive in reaching out to communities and that "we can't just do pamphlets" about the evils of extremism. ${ }^{9}$ An official from Kyrgyzstan spoke about efforts by the prosecutor-general's office to create a website with useful narratives to counter extremist messaging ISIS is using to recruit young men and women to its ranks. At the same time, Central Asian officials and NGO leaders admit that such measures are too passive: It can take months to hammer out the language and format of such anti-extremist messaging, while Daesh churns out glitzier public relations material in a number of hours. Uzbek officials realized this when a glossy, well-produced booklet called "Ishid Fitnasi" ("ISIS Fitna") - designed to caution citizens against the lure of ISIS ideology - received little public attention, despite the expense and effort required in its production. ${ }^{10}$

\section{In the dark}

Any progress in Central Asia towards a more holistic approach to counterterrorism requires a solid understanding of the roots and extent of radicalization in the region. Yet, what we think we know pales relative to what we do not know. For example, there is a sense of the range of numbers of foreign terrorism fighters from Central Asia fighting for ISIS in Iraq and Syria as well as a general understanding of how they are placed within the division of labor of the terrorist-militant network. According to sober estimates, there are 500-1000 fighters from Uzbekistan or of Uzbek origin, 200-1000 from Tajikistan, 250-400 from Kazakhstan, 200-400 from Kyrgyzstan, and 360 from Turkmenistan. ${ }^{11}$ By contrast, there seems to be a more tenuous sense of the dynamics and extent of networks of radicalization within Central Asia.

Publications and studies on the issue reflect existing knowledge gaps. Publications extrapolate patchy data or rely on anecdotal evidence. In the absence of data, some studies describe government counterradicalization policies, while others debate 
definitions of radicalization. Many studies link radicalization to a long list of risk factors that may or may not be relevant across the region.

Extrapolation of anecdotal evidence is perhaps the most common limitation. Authors cite fragmentary data or use their anecdotal observations to gauge radicalization. An article titled "Radicalization Is No Myth", for example, cites evidence that "there are more mosques than schools built in the country each year. There has been a marked increase in Arab Islamic fashion seen on the streets (something previously unusual in Kyrgyzstan), especially among young people. The central mosque, which used to be an empty sightseeing spot for tourists, is now packed on Fridays. Men with beards and dressed in Afghan-style clothing knock on the doors of every house offering Islamic teachings. And then there's the darker side: reportedly, 500 youth from Kyrgyzstan have joined terrorist groups in Syria". ${ }^{12}$ The difficulty with casual observations is that they may or may not be a sign of radicalization; they sidestep well considered comparisons and rest on a series of implications that include reading into the intentions behind people's everyday actions.

Moreover, studies in Central Asia have yielded contradictory findings on the links between religiosity and radicalization. One 2012 study based on extensive polling and focus groups in Tajikistan presented statistics concerning people's perception of the causes of radicalization and the extent of their familiarity with extremist groups. ${ }^{13}$ The study revealed that people tend to learn more about extremist groups from friends and family rather than from religious establishments or mosques. Another UN study on Kyrgyzstan in 2015 warned about unfettered mosque construction in Osh oblast and cited the lack of religious and theological competence among law enforcement agencies. While the first study underplayed the role of religion, the second study ascribed religious cites a central role in radicalization processes.

Other studies focus on government counterradicalization programs. Some are exceptionally researched and highly analytical, such as Noah Tucker's series of articles published by the Central Asia Program on official initiatives to counter the narratives and ideology of violent extremist networks. ${ }^{14}$ These studies reveal the intricacies of government responses to a perceived radicalization problem; yet, lacking a good understanding of the extent of radicalization, it will be difficult to do a full assessment of such programs or retool them accordingly.

The policymaker's task is made more difficult as otherwise useful publications get mired in debates of terms, definitions, and methodology. One recent example is the lengthy rejoinder by Heathershaw and Montgomery to International Crisis Group (ICG) reports, entitled "The Myth of Post-Soviet Radicalization in the Central Asian Republics". ${ }^{15}$ Heathershaw and Montgomery attack a series of claims by ICG that Islamization and radicalization are the same, that authoritarianism and poverty cause radicalization, and that underground Muslim groups are necessarily radical. They fault radicalization studies for using scant and unreliable data and reading too much into isolated incidents. While they cast thought-provoking doubts on the methodologies and 
claims of ICG reports, they do not leave us with an alternate picture of where radicalization begins and ends in the region.

As one expert explained, "while many local and international actors appear to display a strong interest and concern over rising radicalization and religious extremism, the threat itself has not been quantified or qualified and, according to most interlocutors of the UN system, still requires a broader study encompassing regional, national and district level situation analysis". ${ }^{16}$ Until studies like that become more common place, we will be left with long lists of risk factors that are usually cut and pasted from the European setting to Russia and on to Central Asia. ${ }^{17}$

The lack of reliable data and knowledge create a serious policy problem: while Central Asian officials laud the virtues of holistic policies, in the absence of solid data they fall back on what they know best. For example, they continue to favor hard counterterrorism measures to punish or prevent terrorism rather than broader measures that might stem or slow radicalization. Tajikistan's authorities have been particularly active at using the police and prosecutorial systems to jail people they have labelled as radical, including members of nonviolent opposition groups. ${ }^{18}$ This outcome has taken place despite the multi-year effort of the Organization for Security and Cooperation in Europe (OSCE) to assist Tajikistan in drafting a comprehensive counterradicalization and counterterrorism strategy.

While it is easy to lay all the blame on Tajik officials for heavy-handedness, the international community and expert policymakers may be pushing Tajikistan too hard in adopting policies that require a major makeover of its institutions and that do not operate with a clear theory of the drivers of radicalization. The OSCE's understanding of radicalization processes, which is focused on the vulnerability of youth in Tajikistan, relies on a number of vastly broad drivers: unemployment, poverty, labor migration, lack of access to religion, poor religious education, ideological vacuum, perceived lack of future opportunities, and lack of social engagement. ${ }^{19}$ Such factors easily describe a large proportion of youth in rich and poor countries alike and yet Belgian Muslims are 13 times more likely to go to Syria to fight on behalf of ISIS than Tajik youths. ${ }^{20}$

Given so many untested variables, Central Asian authorities tend to favor uncomplicated policies. For instance, many states keep heavily investing in the religious dimension of violent extremism, and they have deployed religious leaders to counter the narratives of Daesh, despite evidence indicating that religious leaders are not effective messengers. As terrorism expert Scott Atran explains, radicalization rarely occurs in mosques and $80 \%$ of foreign terrorist fighters have no religious education. ${ }^{21}$ It is hard to see what imams and religious leaders can do to prevent radicalization, especially if religion is not a motivating force. As one NGO leader who works closely with Central Asian organizations admitted, Internet videos of young religious leaders reciting the Quran and spreading moderate messages have struggled to hit 500 views, despite taking months and substantial funds to produce. ${ }^{22}$

This is not solely a Central Asian problem. As one extensive survey of radicalization studies by Alex Schmid made it clear, when it comes to the drivers of 
radicalization and deradicalization, we are still in the very early stages of knowing what does and doesn't work. ${ }^{23}$ Indeed, the author is careful to qualify existing knowledge in terms of what we think we know given that confidence levels are often not conclusive. What we think we know, indeed, is often embedded in extremely broad variables that are themselves filled with exceptions and caveats. For example, radicalization is usually a gradual, phased process. And yet, some NGOs have found that young people can go from having no contact with terror organizations to becoming radicalized, willing fighters in a matter of weeks. ${ }^{24}$ Individual poverty alone does not cause radicalization towards terrorism, but un(der)employment may play a role. "In other words, it is a myth or at best a half-truth. However in some countries unemployment has been a motive for some young men to join terrorist groups". ${ }^{25}$

If our tentative knowledge is filled with concepts and dynamics that are themselves abstract, hard to quantify, and highly dependent on country and local settings, a more daunting problem is a larger set of questions for which there are no good answers yet:26 Who is most vulnerable to radicalization? How do social networks radicalize individuals? How do we know where a radicalized social network begins and ends? The lack of answers to these questions exacerbates a problem across the Central Asian region mentioned previously: in the absence of solid knowledge, both Central Asian officials and international policymakers will fall back on what they know best - measures that may be either inconsequential or counterproductive.

\section{Learning from Afghanistan}

One place to get better answers to questions about radicalization may lie just to the south of Central Asia. While Central Asian officials are quick to issue warnings about the specter of Afghanistan as a conduit for terrorism into Central Asia, they have taken little notice of the work being conducted in Afghanistan on terrorism and radicalization processes.

Research in Afghanistan has brought us closer to clarifying both what we know and what we do not know on radicalization and the connection to violent extremism. For example, Mohamed Borhan's research with the Afghanistan Analyst Network maps religious youth networks and distinguishes between views that are outside the mainstream and those that are prone to violence. ${ }^{27}$ Research by United Nations Assistance Mission in Afghanistan (UNAMA) has also began to answer questions about the conditions under which local populations - religious or otherwise - will lend support to insurgent and terrorist networks. As a result, there is a pool of intricate, district-bydistrict knowledge of radicalization and violence across Afghanistan, including sober and frequently updated assessments of ISIS inroads in Afghanistan that dispel myths and dispense with exaggeration. ${ }^{28}$ While this work is rarely made public and even less frequently aggregated into big-picture studies, it demonstrates knowledge that can be

gained when national researchers, good methodologies, and forward-thinking international organizations are able to work in tandem with a host government. While 
Afghanistan's security environment is far more dangerous to researchers than Central Asia's, its setting is far more politically permissive to such research. ${ }^{29}$ As a result, we may know more about radicalization in Afghanistan's most dangerous regions than we do even about Central Asia's safest areas.

\section{Leading the charge towards a better understanding}

Better knowledge of the dynamics and extent of radicalization in Central Asia can lead to better policies. Here, there is much that Russia and the United States can do in concert despite their divergent approaches to counterradicalization and counterterrorism. ${ }^{30}$ The U.S. approach has involved substantial local community engagement and sees partnerships with local communities and NGOs as essential to counterradicalization. Russia's approach, which initially experimented with community engagement and softer preventative measures in the period of the Medvedev presidency (2008-2012), has increasingly taken a more coercive approach under President Putin without outwardly radicalizing its Muslim populations. Working together, the United States and Russia can complement each other's approaches and assist the Central Asian states in adopting a more holistic approach to their counterterrorism policies.

There are naturally going to be opponents on both sides to a bilateral approach. Elected officials from both parties in the U.S. are wary of the Trump administration embracing Russia while questions of cybersecurity and European security abound. Some observers in the United States, moreover, believe that Russia's counterterrorism approach and its policies in Syria are building massive grievances in Sunni populations that will trigger greater terrorism down the road - and recommend that the U.S. should steer clear from Russia in this regard. ${ }^{31}$ On the Russian side, there are those who believe that it is time for the United States to fully disengage from Central Asia following its drawdown in Afghanistan and that Moscow should naturally and willingly pick up the slack in the former.

Yet, there are good reasons for the United States and Russia to consider the benefits of cooperating in Central Asia. First, both Washington and Moscow need to find less irking ways to engage one another. As U.S. Secretary of State Rex Tillerson noted on 16 February 2017, the United States would "consider working with Russia where we can find areas of practical cooperation". ${ }^{32}$ Second, it is a good opportunity to shift Russia's counterterrorism efforts closer to the community engagement efforts that it experimented with in the past, provided that the United States does not abandon its own commitments to preventative, community-based approaches under the Trump administration. ${ }^{33}$ Third and most important, Russia and the United States can assist the region's stakeholders in finding sober and evidence-based answers to the questions on radicalization and violence that have eluded them. 
In cooperation with Central Asian governments, Russia and the United States can develop an initiative to better understand and respond to radicalization in the region. This initiative should include:

Speaking with a common voice: While counterradicalization plans should be tailored to each national and local context, states cannot have different road maps on offer if those road maps contradict one another. The U.S. and Russia should speak with a common voice when it comes to counterterrorism and the prevention of violent extremism in Central Asia. ${ }^{34}$

Jointly commission studies: Russia and the United States should jointly fund and commission research on unanswered questions on radicalization specific to the Central Asian context. The research should deploy a mix of methodologies and groups of national and international experts - Including well-heeled researchers from Afghanistan. The studies should be vetted by an independent committee of experts and published in Russian, English, and Central Asian languages to ensure dissemination to all officials whose work includes counterradicalization policies.

Expand training in key areas: As the above studies reveal new answers about violence and radicalization processes in the region, the United States and Russia can use a joint fund to support Central Asian governments' action plans, especially in drafting and revising counterradicalization policies in response to new evidence. It can also include funding training programs in areas that studies cite as the most useful in combating radicalization.

Russia and the United States have the opportunity to work with Central Asian governments to develop evidence-based, tailored programs that make the most of limited time and resources. Otherwise, Central Asian governments will continue to rely on what they know best - a combination of hard security measures and preventive policies that are unproven. Given how little we know, it is not clear whether Central Asia's radicalization problem is relatively small, moderate, or alarmingly large. However, it is clear that if we remain in the dark about radicalization processes, governments will end up spending money diffusely, inefficiently, and with few results.

\section{ENDNOTES}

1 Global Terrorism Index 2016. - Sydney: Institute for Economics and Peace, 2016. P. 10-11. URL: <http://economicsandpeace.org/wp-content/uploads/2016/11/Global-Terrorism-Index-2016.2.pdf>.

2 Afghanistan: Taliban Spring Offensive and Increasing Threat to Central Asia // The Times of Central Asia. 24 April 2016.

3 Attended by author in Bishkek, June 2016.

${ }^{4}$ Author communications with counterterrorism officials in Kazakhstan and Kyrgyzstan. 
5 Cooley A. Great Games, Local Rules: The New Great Power Contest in Central Asia. - Oxford: Oxford University Press, 2012. P. 160.

6 For more detail, see URL: <https://unrcca.unmissions.org/>.

7 Speckhard A., Shajkovci A., Yayla A. What to expect following a military defeat of ISIS in Syria and Iraq // Journal of Terrorism Research. February 2017. V. 8. № 1. P. 81-89.

${ }^{8}$ As suggested in June 2016 by Yerlan Karin, director of the Kazakh Institute of Strategic Studies under the President of the Republic of Kazakhstan. BBC Monitoring Central Asia Unit. 16 July 2016.

${ }^{9}$ Recognizing and Responding to Radicalization that Can Lead to Violent Extremism and Terrorism in Central Asia. Workshop of the United Nations Counter-Terrorism Implementation Task Force and the United Nations Regional Centre for Preventative Diplomacy in Central Asia. - Almaty, Kazakhstan. 29-31 March 2016.

10 Tylepov A. Ishid Fitnasi. - Tashkent: Directorate of Muslims of Uzbekistan, 2015 [in Uzbek]. The book's approach included using moderate Islamist theology and historical treatises from Hazret Ali on the dangers of strife and sedition posed by ISIS and its corruption of Islam. "When you see a black flag, don't leave your house... don't stir your hands and feet. That is to say, do not offer them financial or moral support." "Qachon qora bayroqlarni ko'rsangiz, uyingizdan jilmang...qo'l va oyoqlaringizni qimirlatmang. Ya'ni ularga moddiy-ma'naviy yordam bermang."

11 While some give much higher numbers for Central Asian citizens who have joined ISIS (for instance, Vitali Naumkin recently suggested there are 5000(, Noah Tucker provides the more moderate range cited here. See Expert says Middle East problems directly affect Caucasus and Central Asia // TASS Russian News Agency. 9 March 2017; Tucker N. Public and State Responses to ISIS Messaging: Case Studies on Kazakhstan, Kyrgyzstan, Tajikistan, Turkmenistan, and Uzbekistan. The Central Eurasia - Religion in International Affairs (CERIA) Briefs. Central Asia Program, George Washington University. February 2016.

URL: <http://centralasiaprogram.org/blog/2016/02/16/public-and-state-responses-to-isis-messaging>.

12 Masylkanova A. Radicalization in Kyrgyzstan is no myth // The Diplomat. 22 June 2016.

URL: <http://thediplomat.com/2016/06/radicalization-in-kyrgyzstan-is-no-myth/>.

13 Taarnby M. Islamist Radicalization in Tajikistan: An Assessment of Current Trends. Korshinos Center for Socio-Political Studies. - Dushanbe, 2012.

14 Tucker N. Op. cit.

15 Heathershaw J., Montgomery D. The Myth of Post-Soviet Muslim Radicalization in the Central Asian Republics. Russia and Eurasia Programme Research Paper. L.: Chatham House, November 2014. URL: <https://www.chathamhouse.org/sites/files/chathamhouse/field/field_document/201411 11PostSovietRadicalizationHeathershawMontgomeryFinal.pdf>.

16 United Nations Country Team in the Kyrgyz Republic. DRAFT STUDY.

17 Experts at Hedayah warn against the cut-and-paste approach. See Guidelines and Good Practices: Developing National P/CVE Strategies and Action Plans - Hedayah. September 2016. URL: <http://www.hedayahcenter.org/Admin/Content/File-1792016192156.pdf>. 
18 Khamidova P. Interview with Muhiddin Kabiri, Leader of the Islamic Renaissance Party of Tajikistan in-Exile. Central Asian Program, George Washington Universoty. Central Asia Policy Brief. № 33. January 2016; Rotar I. Political Islam in Tajikistan after the Formation of the IS. CERIA Brief. № 8. October 2015. URL: <http://centralasiaprogram.org/blog/2015/10/19/political-islam-in-tajikistanafter-formation-of-the-is/>.

19 Personal communication.

20 A point Ed Lemon makes cogently: see Kucera J. State Department downplays ISIS threat in Central Asia // Eurasianet. 12 June 2015. URL: <http://www.eurasianet.org/node/73836>.

21 Atran S. Briefing to United Nations Security Council Committee on Counter Terrorism. New York, 24 November 2015. URL: <http://artisinternational.org/wp-content/uploads/2011/02/Atran-Brief-toUN-Security-Council-CT.pdf>.

22 Author communication with Central Asian NGO director and counter-radicalization experts.

23 Schmid A. Radicalization, De-Radicalization, Counter-Radicalization: A Conceptual Discussion and Literature Review. ICT Research Paper, March 2013. P. 20.

24 Personal communication with director of NGO specializing in radicalization.

25 Schmid A. Op. cit. P. 20.

26 Ibid. P. 31.

27 Osman B. Beyond Jihad and Traditionalism: Afghanistan's New Generation of Islamic Activists. Afghanistan Analysts Network Thematic Reports. January 2015. URL: <https://www.afghanistananalysts.org/wp-content/uploads/2015/06/AAN-Paper-012015-Borhan-Osman-.pdf>.

${ }^{28}$ Author communication.

29 Author's communication with researchers denied visas. Also see: Authorities detain Tajik researcher, whereabouts uncertain // Eurasianet.org. 17 June 2014.

30 Stepanova E. How and Why the United States and Russia Can Cooperate on Terrorism. PONARS Eurasia Policy Memo № 450. November 2016.

URL: <http://www.ponarseurasia.org/node/8787>.

31 Aron L. The coming of the Russian Jihad, Part II // War on the Rocks. 18 December 2016.

32 Welt C. Russia: Background and U.S. Interests. Congressional Research Service Report № R44775. - Washington D.C.: CRS, 1 March 2017.

${ }^{33}$ Currently, a number of U.S. CVE/PVE community-engagement programs have been frozen by the Trump Administration, including in the Department of Justice.

34 This should include a "do no harm" approach to the international commitments that Central Asian governments have signed, including to the emerging United Nations Plan of Action to Prevent Violent Extremism, The United Nations Global Counterterrorism Strategy. Plan of Action to Prevent Violent Extremism: Report of the Secretary General. 24 December 2015. 